\title{
Ehrlichia spp. infection in rural dogs from remote indigenous villages in north-eastern Brazil
}

\author{
Filipe Dantas-Torres ${ }^{1,2^{*}} \mathbb{D}$, Yury Yzabella da Silva', Débora Elienai de Oliveira Miranda',
} Kamila Gaudêncio da Silva Sales ${ }^{1}$, Luciana Aguiar Figueredo ${ }^{1}$ and Domenico Otranto ${ }^{2}$

\begin{abstract}
Background: Ehrlichia canis is a tick-borne bacterium that causes severe, life-threatening disease in dogs, being more prevalent in tropical and subtropical countries. Randomized studies conducted in Brazil indicate that the prevalence of $E$. canis infection in dogs ranges from $0.7 \%$ to over $50.0 \%$. In a study conducted in northern Brazil, the prevalence was higher in dogs from urban areas, as compared to dogs from rural areas. In the present study, we investigated the exposure to Ehrlichia spp. infection in dogs from remote indigenous villages located in a rural area in north-eastern Brazil.

Methods: From March to June 2015, 300 privately owned dogs were blood sampled and tested by a rapid ELISA and by a conventional PCR in order to detect anti-Ehrlichia spp. antibodies and E. canis DNA, respectively. Additionally, dogs were also tested for anti-Anaplasma spp. antibodies and Anaplasma platys DNA, using the same diagnostic approaches. Positivity was correlated with tick infestation and dogs' data (gender, age and level of restriction).

Results: Overall, 212 (70.7\%) dogs were positive for at least one test targeting Ehrlichia spp. In particular, 173 (57.7\%) dogs were positive only by rapid ELISA, $5(1.7 \%)$ only by PCR and 34 (11.4\%) were simultaneously positive by both tests. In the same way, 39 (13.0\%) dogs presented detectable E. canis DNA in their blood, whereas 18 (6.0\%) dogs were A. platys DNApositive. Coupling serological and PCR data, 63 (21.0\%) dogs were simultaneously positive to Ehrlichia spp. and Anaplasma spp. Positivity rates for both Ehrlichia spp. and Anaplasma spp. were higher among dogs more than 1 year of age. Sick dogs were more positive to Ehrlichia spp. as compared to healthy dogs.

Conclusions: Dogs from rural areas in north-eastern Brazil are highly exposed to Ehrlichia spp. infection and positivity rates do not necessarily correlate with current tick infestation load, since only one infected tick bite is needed to get the infection. This reinforces the importance of keeping dogs free of ticks, in order to reduce as much as possible the risk of infection by $E$. canis and other tick-borne pathogens such as Babesia vogeli, which are usually co-endemic.
\end{abstract}

Keywords: Ehrlichia canis, Ticks, Rhipicephalus sanguineus (sensu lato), Brazil

\section{Background}

Canine monocytic ehrlichiosis is a life-threatening tick-borne disease characterized by nonspecific clinical signs, such as fever, weakness, lethargy, anorexia, lymphadenomegaly, splenomegaly, hepatomegaly and weight loss [1]. The disease is caused by the intracellular bacterium Ehrlichia canis, which affects dogs worldwide, being more prevalent in tropical and

\footnotetext{
*Correspondence: filipe.dantas@cpqam.fiocruz.br

'Department of Immunology, Aggeu Magalhães Institute, Oswaldo Cruz Foundation (Fiocruz), Recife, Brazil

${ }^{2}$ Department of Veterinary Medicine, University of Bari, Valenzano, Italy
}

subtropical regions, where the brown dog tick Rhipicephalus sanguineus (sensu lato), the primary tick vector, is abundant [2]. For instance, prevalence rates of E. canis infection in dogs range from less than $1 \%$ up to $50 \%$ in Europe and it is higher in kennelled dogs and in dogs without external antiparasitic treatment [1]. Indeed, E. canis is endemic in all European countries bordering the Mediterranean Sea [1], where the tick vectors are highly abundant, particularly from spring to autumn [3].

The prevalence of $E$. canis infection in dogs varies according to several factors, but generally correlates with the level of exposure to infected tick vectors. Studies 
have reported higher positivity rates among males as compared to females and among older dogs as compared with young ones [1]. This is probably related to behavioural characteristics of males, which increase their level of exposure to the tick vectors in comparison with females. The same applies for age since the probability of becoming infected increases as the dog ages. Breedrelated susceptibility has also been suggested by epidemiological and experimental studies. Indeed, German shepherd dogs and Siberian Huskies are predisposed to developing more severe clinical signs $[4,5]$.

Canine monocytic ehrlichiosis is a very common disease in Brazil, where dogs are highly exposed to brown dog ticks [6, 7]. Randomized studies conducted in several regions of Brazil indicate that the prevalence of $E$. canis infection in dogs ranges from $0.7 \%$ to over $50.0 \%$ [7-10]. A study conducted in Roraima, northern Brazil, reported that the prevalence of $E$. canis infection was higher in dogs from urban areas, as compared to dogs from rural areas [11], whereas a more recent study conducted in Paraná, southern Brazil, indicated the opposite [12].

Recently, we reported a high level (58\%) of exposure to Ehrlichia spp. among privately owned dogs living in Goiana [6], a city situated in the north-east region of Pernambuco State, north-eastern Brazil. In the present study, we investigated the exposure to Ehrlichia spp. infection in rural dogs from remote indigenous villages in the countryside of Pernambuco State.

\section{Methods}

\section{Study area and sample size calculation}

The present randomised prevalence study was conducted in four indigenous villages in the municipality of Pesqueira $\left(08^{\circ} 21^{\prime} 42^{\prime \prime} \mathrm{S}, 36^{\circ} 41^{\prime} 41^{\prime \prime W} ; 654 \mathrm{~m}\right.$ above sea level), Pernambuco State. Members of the tribe Xukuru de Ororubá inhabit these villages, which are located in the scrub zone of Pernambuco, $204 \mathrm{~km}$ far from Recife, the state's capital. Semi-restricted or unrestricted dogs are frequent in these villages and are commonly used as guard or as pets. The climate is semi-arid, hot and dry, with annual average temperature of $23{ }^{\circ} \mathrm{C}$ and average precipitation of $700 \mathrm{~mm}$, with rains concentrated from February to July.

For this study, the minimum sample size $(n=243)$ was calculated considering a margin of error of $5 \%$, a confidence level of $95 \%$, a population size of 20,000 (unknown), and an expected prevalence of $20.0 \%$, based on the average prevalence found in a large study conducted in Brazil [13].

\section{Physical examination and blood sampling}

From March to June 2015, a total of 300 privately owned dogs were visited by a veterinarian and by a field team in previously selected indigenous villages. Each dog was physically examined for clinical signs suggestive of vector-borne diseases, including weight loss, pale mucous membranes, enlarged lymph nodes and petechiae.

The number of ticks and fleas was estimated by the attending veterinarian, during the physical examination, through visual inspection. The level of infestation was classified as negative (no ticks or fleas), low (1-3 ticks and 1-5 fleas), moderate (4-10 ticks and 6-20 fleas) and high (> 10 ticks and $>20$ fleas) [14]. Ticks, fleas and also lice were manually collected and preserved in labelled vial containing 70\% ethanol for later morphological identification $[15,16]$.

Dogs were physically restrained by their owners and blood samples $(\sim 5 \mathrm{ml})$ were withdrawn from their cephalic, jugular or femoral veins. An aliquot $(\sim 2 \mathrm{ml})$ was placed in an EDTA tube (Vacuette ${ }^{\circ}$ K3E K3EDTA tube, Greiner Bio-One $\mathrm{GmbH}$, Kremsmünster, Austria) and other $(\sim 3 \mathrm{ml})$ in a serum separator tube (Vacuette ${ }^{\circ}$ Z Serum Separator Clot Activator tube, Greiner BioOne $\mathrm{GmbH}$ ). Samples were maintained on ice until processing. In the laboratory, EDTA-treated blood samples were frozen at $-20{ }^{\circ} \mathrm{C}$ until DNA extraction using PureLink ${ }^{\circ}$ Genomic DNA Mini Kit (Invitrogen, Carlsbad, USA), according to the manufacturer's instructions. Serum separator tubes were centrifuged at 2,000x $g$ for $10 \mathrm{~min}$ and obtained serum samples were frozen at $-20{ }^{\circ} \mathrm{C}$ until serological testing.

\section{Diagnostic testing}

Serum samples were tested by a rapid ELISA (SNAP ${ }^{\circ}$ 4Dx Plus Test, IDEXX Laboratories, Maine, USA), which detects antibodies to Anaplasma spp. (A. platys/A. phagocytophilum), Ehrlichia spp. (E. canis/E. ewingii), Borrelia burgdorferi, and antigens of Dirofilaria immitis. All tests were performed according to the manufacturer's instructions.

Ehrlichia canis DNA was detected by conventional PCR amplifying a $410 \mathrm{bp}$ fragment of the heat shock protein $(g r o E L)$ gene using the species-specific primers gro-E.canis163s and groEcanis573as [17]. Each reaction mixture contained $7.5 \mu \mathrm{l}$ of DNA-free water, $1.5 \mu \mathrm{l}$ of each primer at a concentration of $10 \mathrm{pmol} / \mu \mathrm{l}, 12.5 \mu \mathrm{l}$ GoTaq $^{\circ}$ Colorless Master Mix (Promega, Madison, USA) and $2 \mu \mathrm{l}$ of the sample DNA to be tested, totalling $25 \mu \mathrm{l}$. Thermal cycling conditions were as follows: initial denaturation at $95^{\circ} \mathrm{C}$ for $30 \mathrm{~s}$, followed by 40 cycles of $94^{\circ}$ $\mathrm{C}$ for $10 \mathrm{~s}, 62{ }^{\circ} \mathrm{C}$ for $15 \mathrm{~s}$ and $72{ }^{\circ} \mathrm{C}$ for $15 \mathrm{~s}$, with a final extension of $72{ }^{\circ} \mathrm{C}$ for $1 \mathrm{~min}$.

Anaplasma platys DNA was detected by conventional PCR amplifying a $515 \mathrm{bp}$ region of the groEL gene using the species-specific primers GroAplatys-35s and GroAplatys-550as [18]. Each reaction contained $7.5 \mu \mathrm{l}$ of DNA-free water, $12.5 \mu \mathrm{l}$ of $\mathrm{GoTaq}^{\bullet}$ Colorless Master Mix (Promega), $1.5 \mu \mathrm{l}$ of each primer at a concentration 
of $10 \mathrm{pmol} / \mu \mathrm{l}$ and $2 \mu \mathrm{l}$ of DNA sample, totalling $25 \mu \mathrm{l}$. Thermal cycling conditions were as follows: initial denaturation at $95{ }^{\circ} \mathrm{C}$ for $1 \mathrm{~min}$, followed by 55 cycles of $94{ }^{\circ} \mathrm{C}$ for $15 \mathrm{~s}, 62{ }^{\circ} \mathrm{C}$ for $15 \mathrm{~s}$ and $72{ }^{\circ} \mathrm{C}$ for $15 \mathrm{~s}$.

DNA extracted from naturally infected dogs (with $E$. canis or A. platys) was used as positive control and DNA-free water as negative control. PCR products were separated by electrophoresis in a 1.5\% agarose gel, stained with ethidium bromide, and visualised by UV transillumination.

\section{Data analysis}

The $95 \%$ confidence intervals $(95 \% \mathrm{CI})$ of positivity rates were calculated. The Chi-square $\left(\chi^{2}\right)$ or G-test was used to compare positivity rates relative to sex (male $v s$ female), age ( $\leq 1$ year $v s>1$ year), clinical status (healthy, sick), level of tick/flea infestation (absent $v s$ low $v s$ moderate $v s$ high), and level of restriction (restricted $v s$ semi-restricted). The differences were considered statistically significant when $P \leq 0.05$. Statistical analysis was performed using BioEstat, version 5.3 [19].

\section{Results}

All 300 dogs included in the present study were mongrels, of which 179 (59.7\%) were males and 121 $(40.4 \%)$ were females. The great majority of the dogs were $>1$ year old $(77.4 \%)$ and presented at least one clinical sign suggestive of vector-borne diseases (59.7\%). Thirty-five (11.7\%) dogs were considered restricted and 265 (88.4\%) semi-restricted.

Ticks were detected in 91 (30.4\%; 95\% CI: $25.1-35.5 \%)$ dogs, of which 19 (20.9\%) presented high, 23 (25.3\%) medium and 49 (53.9\%) low levels of infestation. Most ticks collected (97.3\%) were identified as $R$. sanguineus (s.l.) (157 males, 100 females and 28 nymphs). Four dogs were also infested by Amblyomma parvum (5 females) and 2 by Rhipicephalus microplus (3 females). By comparing tick infestation levels and positivity rates to both Ehrlichia spp. $\left(\chi^{2}=3.235, d f=3, P=0.3568\right)$ and Anaplasma spp. ( $G=2.3918, d f=1, P=0.4952)$, no significant differences were found. Fleas were observed in 133 (44.4\%; 95\% CI: 38.7-50.0\%) dogs, of which 29 (21.8\%) presented high, $33(24.9 \%)$ medium and 71 (53.4\%) low levels of infestation. All fleas collected (40 males and 73 females) were identified as Ctenocephalides felis felis. By comparing flea infestation levels and positivity rates to Ehrlichia spp. $\left(\chi^{2}=10.099, d f=3, P=0.0177\right)$, a significant difference was found. Indeed, the highest positivity rate to Ehrlichia spp. (76.1\%) was recorded among flea-free dogs. No significant difference was found in relation to Anaplasma spp. positivity and flea infestation $\left(\chi^{2}=1.544, d f=3, P=0.6722\right)$.
In addition to ticks and fleas, eight dogs were infested by lice, which were all identified as Heterodoxus spiniger (7 males, 14 females and 4 nymphs).

Overall, 212 (70. 7\%; 95\% CI: 65.5-75.8\%) dogs were positive for at least one test targeting Ehrlichia spp. In particular, $173(57.7 \%)$ dogs were positive only by rapid ELISA, 5 (1.7\%) only by PCR and 34 (11.4\%) were simultaneously positive by both tests. Anaplasma spp. infection was detected in 72 (24.0\%; 95\% CI: 19.2-28.8\%) dogs, of which 54 (18.0\%) were positive only by rapid ELISA, 11 (3.7\%) only by PCR and 7 (2.4\%) were simultaneously positive by both tests. Sixty-three (21.0\%) dogs were simultaneously positive to Ehrlichia spp. and Anaplasma spp. Positivity rates for both Ehrlichia spp. $\left(\chi^{2}=40.662, d f=1\right.$, $P=0.0001)$ and Anaplasma spp. $\left(\chi^{2}=4.164, d f=1\right.$, $P=0.0413)$ were higher among dogs more than 1 year of age. Sick dogs were more exposed to Ehrlichia spp. $\left(\chi^{2}=6.039, d f=1, P=0.0140\right)$ as compared to healthy dogs. Statistical data on comparisons made between different variables and positivity rates to both Ehrlichia spp. and Anaplasma spp. are summarised in Table 1.

\section{Discussion}

Our results indicate that dogs from rural areas in northeastern Brazil are highly exposed to Ehrlichia spp. infection, in spite of the relatively low prevalence of tick infestation (30.33\%) found in the studied population. Considering that most rural dogs are semi-restricted or unrestricted and usually untreated against ticks, the low prevalence of tick infestation was unexpected. Indeed, in other studies conducted in Pernambuco, the prevalence of tick infestation ranged from $41.7 \%$ [6] to $58.5 \%$ [20] in urban and rural dogs, respectively. As an example, a recent study carried out in south-western Pernambuco, indicated that rural dogs were generally more infested by both ticks and fleas, as compared with urban dogs [21] with a tick infestation rate ranging from $44.4 \%$ to $50.8 \%$ in urban and rural dogs, respectively. Overall, this is in agreement with previous studies conducted in Pernambuco [6, 20]. However, we should keep in mind that, besides environmental conditions (e.g. rural versus urban landscapes), the level of ectoparasite infestation in dogs is also related to other factors, including the owner's capability to afford preventive measures [6] and therefore, the risk of tick infestation might be extremely high in urban dogs as well. In a study conducted in the Metropolitan region of Recife, tick infestation rates reached $79.3 \%$ in owned dogs attended at a public veterinary clinic and $93.3 \%$ in stray dogs [22]. It is worth mentioning that stray dogs may act as reservoirs of many kinds of parasites, especially in low-income countries [23].

Considering the low percentage of tick-infested dogs, one would expect a low level of exposure to tick-borne pathogens. Unexpectedly, we found a high positivity rate (70.67\%) to Ehrlichia spp. Most randomized studies 


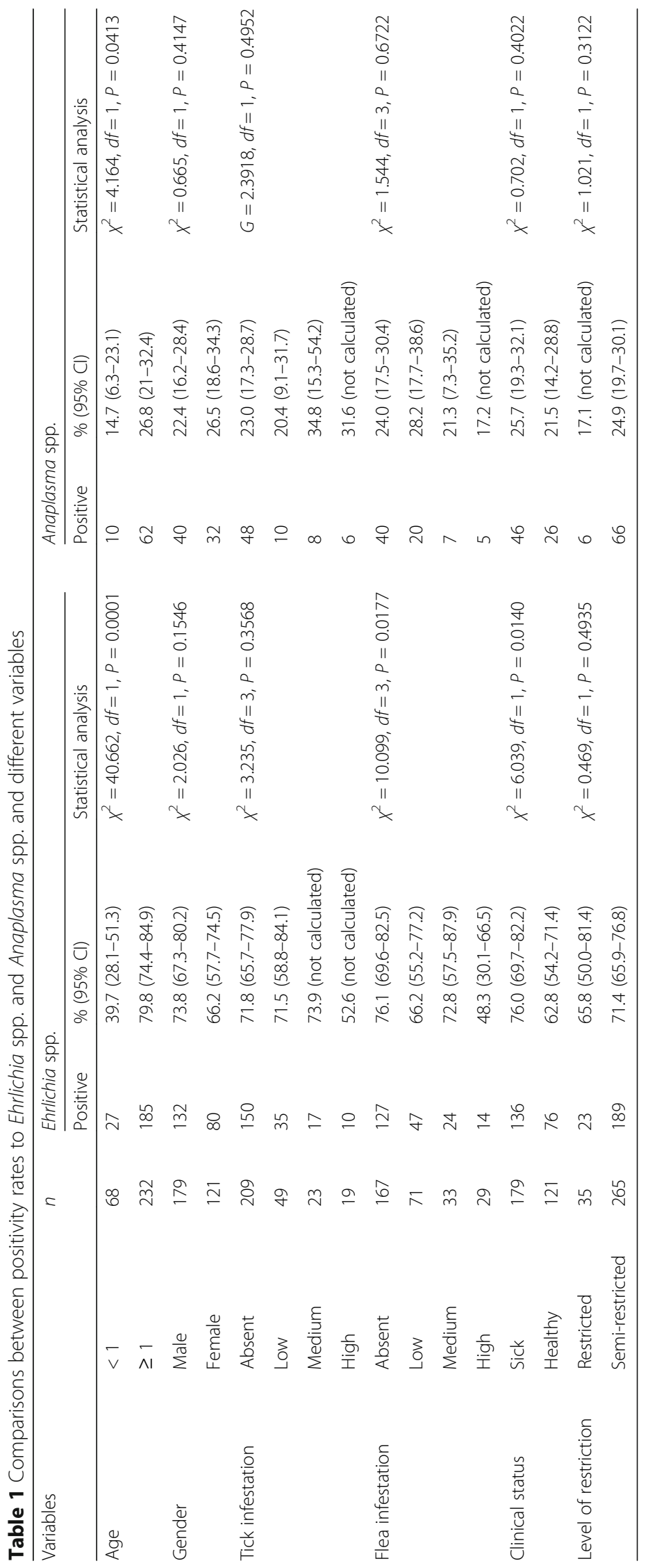


carried out in Brazil suggest that the prevalence of $E$. canis infection in dogs hardly ever surpasses 50.0\% [7], whereas in non-randomized studies on dogs presenting suggestive clinical signs of canine monocytic ehrlichiosis, it may reach over $90.0 \%$ (e.g. [24]). In our study, the positivity rate among dogs displaying suggestive clinical signs was $76.0 \%$, being significantly higher $\left(x^{2}=6.039\right.$, $d f=1, P=0.0140)$ than that detected in healthy dogs $(62.8 \%)$. This is relevant also considering that "prevalence studies" conducted with dogs attended at veterinary hospitals or clinics, might be biased, overestimating the actual prevalence of $E$. canis infection.

Two studies comparing the positivity rates to E. canis in urban versus rural dogs reported that urban ones were significantly more exposed to the infection [11, 12]. Altogether, these findings suggest that both rural and urban dogs might be highly exposed to E. canis infection, and that the risk of infection is not necessarily linked to the level of tick infestation. Indeed, in theory, only one infected tick feeding for some hours is sufficient for transmission to occur.

For quite some time, it has been acknowledged that the longer the tick blood-feeding period, the higher the risk of pathogen transmission. Pioneer studies conducted at the dawn of the 1900s indicated that ticks usually required a ten hour feeding period to transmit Rickettsia rickettsii (the causative agent of Rocky Mountain spotted fever) to vertebrate hosts $[25,26]$. However, ticks that had previously fed on another host (interrupted feeding) required a shorter period (minimum of one hour and 45 minutes) to transmit the bacterium or even less, as recently demonstrated [27]. In recent decades, our knowledge on the transmission times of several tick-borne pathogens has increased considerably [28]. For instance, it has been ascertained that $E$. canis requires a minimum period of three hours to be transmitted by $R$. sanguineus (s.l.) to a susceptible vertebrate host [29]. This information is of practical significance, particularly when planning prevention strategies against E. canis, using repellent, fast killing products.

\section{Conclusions}

Altogether, our results indicate that dogs from rural areas in north-eastern Brazil are highly exposed to Ehrlichia spp. infection and that positivity rates do not necessarily correlate with tick infestation load; that is to say, only one infected tick bite is needed to get a dog infected. This reinforces the importance of keeping dogs free of ticks, in order to reduce as much as possible to risk of infection by $E$. canis and other tick-borne pathogens such as Babesia vogeli, which are usually co-endemic.

\section{Abbreviations}

EDTA: ethylenediamine tetraacetic acid; DNA: deoxyribonucleic acid;

ELISA: enzyme-linked immunosorbent assay; PCR: polymerase chain reaction; UV: ultraviolet; Cl: confidence interval; s.l: sensu lato; $d$ : degrees of freedom

\section{Acknowledgements}

This publication has been sponsored by Bayer Animal Health in the framework of the 13th CVBD World Forum Symposium.

\section{Funding}

This research was funded by PPSUS-FACEPE (project APQ-0281-2.13/13). Idexx Laboratories provided the serological kits.

Availability of data and materials

All relevant data are within the paper.

\section{Authors' contributions}

FDT conceived the study. KGSS and LAF conducted the fieldwork. YYS and DEOM conducted the laboratory testing. FDT conducted the literature review and wrote the manuscript. DO participated in data interpretation and reviewed the manuscript. All authors read and approved the final manuscript.

\section{Ethics approval and consent to participate}

Samples collection and testing was approved (number 56/2013) by the Animal Ethics Committee (CEUA) of the Aggeu Magalhães Institute (Fiocruz), Recife, Brazil. All owners signed an informed consent form.

Consent for publication

Not applicable.

Competing interests

The authors declare that they have no competing interests.

\section{Publisher's Note}

Springer Nature remains neutral with regard to jurisdictional claims in published maps and institutional affiliations.

Received: 20 November 2017 Accepted: 22 February 2018

Published online: 20 March 2018

\section{References}

1. Sainz Á, Roura X, Miró G, Estrada-Peña A, Kohn B, Harrus S, et al. Guideline for veterinary practitioners on canine ehrlichiosis and anaplasmosis in Europe. Parasit Vectors. 2015:8:75

2. Groves MG, Dennis GL, Amyx HL, Huxsoll DL. Transmission of Ehrlichia canis to dogs by ticks (Rhipicephalus sanguineus). Am J Vet Res. 1975;36:937-40.

3. Lorusso V, Dantas-Torres F, Lia RP, Tarallo VD, Mencke N, Capelli G, et al. Seasonal dynamics of the brown dog tick, Rhipicephalus sanguineus, on a confined dog population in Italy. Med Vet Entomol. 2010;24:309-15.

4. Nyindo M, Huxsoll DL, Ristic M, Kakoma I, Brown JL, Carson CA, et al. Cell-mediated and humoral immune responses of German Shepherd Dogs and Beagles to experimental infection with Ehrlichia canis. Am J Vet Res. 1980;41:250-4

5. Harrus $\mathrm{S}$, Kass PH, Klement E, Waner T. Canine monocytic ehrlichiosis: a retrospective study of 100 cases, and an epidemiological investigation of prognostic indicators for the disease. Vet Rec. 1997;141:360-3.

6. Figueredo LA, Sales KGS, Deuster K, Pollmeier M, Otranto D, Dantas-Torres F. Exposure to vector-borne pathogens in privately owned dogs living in different socioeconomic settings in Brazil. Vet Parasitol. 2017;243:18-23.

7. Vieira RFC, Biondo AW, Guimarães AMS, Santos AP, Santos RP, Dutra LH, et al. Ehrlichiosis in Brazil. Rev Bras Parasitol Vet. 2011;20:1-12.

8. Vieira FT, Acosta ICL, Martins TF, Filho JM, Krawczak FDS, Barbieri ARM, et al. Tick-borne infections in dogs and horses in the state of Espírito Santo, Southeast Brazil. Vet Parasitol. 2018;249:43-8.

9. Rotondano TEF, Krawczak FDS, Barbosa WO, Moraes-Filho J, Bastos FN, Labruna MB, et al. Ehrlichia canis and Rickettsia spp. in dogs from urban areas in Paraiba State, northeastern Brazil. Rev Bras Parasitol Vet. 2017;26: $211-5$. 
10. Gottlieb J, André MR, Soares JF, Gonçalves LR, Tonial de Oliveira M, Costa MM, et al. Rangelia vitalii, Babesia spp. and Ehrlichia spp. in dogs in Passo Fundo, state of Rio Grande do Sul, Brazil. Rev Bras Parasitol Vet. 2016;25:172-8.

11. Aguiar DM, Saito TB, Hagiwara MK, Machado RZ, Labruna MB. Diagnóstico sorológico de erliquiose canina com antígeno brasileiro de Ehrlichia canis. Ciência Rural. 2007;37:796-802.

12. Vieira TS, Vieira RF, Nascimento DA, Tamekuni $K$, Toledo $R$ dos $S$, Chandrashekar $\mathrm{R}$, et al. Serosurvey of tick-borne pathogens in dogs from urban and rural areas from Parana State, Brazil. Rev Bras Parasitol Vet. 2013;22:104-9.

13. Labarthe N, de Campos Pereira M, Barbarini O, McKee W, Coimbra CA, Hoskins J. Serologic prevalence of Dirofilaria immitis, Ehrlichia canis, and Borrelia burgdorferi infections in Brazil. Vet Ther. 2003:4:67-75.

14. Marchiondo AA, Holdsworth PA, Green P, Blagburn BL, Jacobs DE. World Association for the Advancement of Veterinary Parasitology (W.A.A.V.P.) guidelines for evaluating the efficacy of parasiticides for the treatment, prevention and control of flea and tick infestation on dogs and cats. Vet Parasitol. 2007;145:332-44.

15. Dantas-Torres F, Otranto D. Dogs, cats, parasites, and humans in Brazil: opening the black box. Parasit Vectors. 2014;7:22

16. Barros-Battesti DM, Arzua M, Bechara GH. Carrapatos de importância médico-veterinária da região neotropical: um guia ilustrado para identificação de espécies. In: São Paulo: Vox/ICTTD-3/Butantan; 2006.

17. Otranto D, de Caprariis D, Lia RP, Tarallo V, Lorusso V, Testini G, et al. Prevention of endemic canine vector-borne diseases using imidacloprid $10 \%$ and permethrin $50 \%$ in young dogs: a longitudinal field study. Vet Parasitol. 2010;172:323-32.

18. Beall MJ, Chandrashekar R, Eberts MD, Cyr KE, Diniz PP, Mainville C. Serological and molecular prevalence of Borrelia burgdorferi, Anaplasma phagocytophilum, and Ehrlichia species in dogs from Minnesota. Vector Borne Zoonotic Dis. 2008:8:455-64.

19. Ayres M, Ayres M, Ayres DL, dos Santos AS. BioEstat 5.0 - aplicações estatísticas nas áreas das ciências biológicas e médicas. Belém: Sociedade Civil Mamirauá; 2007

20. Dantas-Torres F, Melo MF, Figueredo LA, Brandão-Filho SP. Ectoparasite infestation on rural dogs in the municipality of São Vicente Férrer, Pernambuco, northeastern Brazil. Rev Bras Parasitol Vet. 2009;18:75-7.

21. Araes-Santos Al, Moraes-Filho J, Peixoto RM, Spolidorio MG, Azevedo SS, Costa MM, Labruna MB, Horta MC. Ectoparasite infestations and canine infection by rickettsiae and ehrlichiae in a semi-arid region of northeastern Brazil. Vector Borne Zoonotic Dis. 2015;15:645-51.

22. Dantas-Torres F, Figueredo LA, Faustino MG. Ectoparasitos de cães provenientes de alguns municípios da região metropolitana do Recife, Pernambuco, Brasil. Rev Bras Parasitol Vet. 2004;13:151-4.

23. Otranto D, Dantas-Torres F, Mihalca AD, Traub RJ, Lappin M, Baneth G. Zoonotic parasites of sheltered and stray dogs in the era of the global economic and political crisis. Trends Parasitol. 2017;33:813-25.

24. Oliveira D, Nishimori CT, Costa MT, Machado RZ, Castro MB. Anti-Ehrlichia canis antibodies detection by "Dot-Elisa" in naturally infected dogs. Rev Bras Parasitol Vet. 2000;9:1-5.

25. Ricketts HT, Ricketts HT. Some aspects of Rocky Mountain spotted fever as shown by recent investigations. Medical Record. 1909;76:843-55.

26. Moore JJ. Time relationships of the wood tick in the transmission of Rocky Mountain spotted fever. J Infect Dis. 1911;8:339-47.

27. Saraiva DG, Soares HS, Soares JF, Labruna MB. Feeding period required by Amblyomma aureolatum ticks for transmission of Rickettsia rickettsii to vertebrate hosts. Emerg Infect Dis. 2014;20:1504-10.

28. Otranto D. Arthropod-borne pathogens of dogs and cats: From pathways and times of transmission to disease control. Vet Parasitol. 2018:251:68-77.

29. Fourie JJ, Stanneck D, Luus HG, Beugnet F, Wijnveld M, Jongejan F. Transmission of Ehrlichia canis by Rhipicephalus sanguineus ticks feeding on dogs and on artificial membranes. Vet Parasitol. 2013;197:595-603.

\section{Submit your next manuscript to BioMed Central and we will help you at every step:}

- We accept pre-submission inquiries

- Our selector tool helps you to find the most relevant journal

- We provide round the clock customer support

- Convenient online submission

- Thorough peer review

- Inclusion in PubMed and all major indexing services

- Maximum visibility for your research

Submit your manuscript at www.biomedcentral.com/submit
) Biomed Central 